\title{
KONTEKS RELIGIO-POLITIK PERKEMBANGAN SUFISME: Telaah Konsep Mahabbah dan Ma'rifah
}

\author{
Mutohharun Jinan \\ Fakultas Agama Islam Universitas Muhammadiyah Surakarta \\ E-Mail: mutohharun.jinan@ums.ac.id
}

\begin{abstract}
This paper discusses the essence of the concepts of Sufism (Sufism) mahabbah and ma'rifah and how and in what context the concepts of Sufism are formulated. These two concepts are the teachings of Sufism from three Sufi figures namely Rabi'ah al-Adawiyah, Zunnun al-Mishri and al-Gahazali. Can be concluded that the three Sufis in laying the foundations of Sufism teachings did not escape from the context of his time. Rabi'a and Zunnun both live in situations where people are busy taking care of the exoteric things that do not penetrate to the esoteric dimensions of Islam. Both have shifted from the paradigm of worship held by Muslims of his day, from fear of God to love to God. While al-Ghazali lives in a state of contradiction between various Islamic groups. Mahabbah and ma'rifah taught by the three Sufis is the implementation of piety in the process of truth-seeking encompassing plurality and cosmopolitanism in a phase of civilization.
\end{abstract}

Keywords: mahabbah, ma'rifah, sufisme

\begin{abstract}
Abstrak: Makalah ini membahas hakikat konsep-konsep tasawuf (sufisme) mahabbah dan ma'rifah dan bagaimana dan dalam konteks apa konsep-konsep tasawuf itu dirumuskan. Kedua konsep ini merupaka ajaran tasawuf dari tiga tokoh sufi yaitu Rabi'ah al-Adawiyah, Zunnun al-Mishri dan alGahazali. Dapat disimpulkan bahwa ketiga sufi dalam meletakkan dasar-dasar ajaran tasawuf tidak luput dari konteks zamannya. Rabi'ah dan Zunnun sama-sama hidup dalam situasi dimana umat sibuk mengurus hal-hal yang sifatnya eksoteris yang tidak menembus pada dimensi esoteris Islam. Keduanya telah menggeser dari paradigma ibadah yang dipegangi oleh umat Islam di zamannya, dari takut kepada Allah menjadi cinta kepada Allah. Sedangkan al-Ghazali hidup dalam keadaan pertentangan antar berbagai golongan Islam. Mahabbah dan ma'rifah yang diajarkan oleh ketiga sufi merupakan implementasi kesalehan dalam proses pencarian kebenaran yang dilingkupi pluralitas dan kosmopolitanisme dalam suatu fase peradaban.
\end{abstract}

Kata Kunci: mahabbah, ma'rifah, sufisme

\section{PENDAHULUAN}

Penilaian yang proporsional terhadap tasawuf (sufisme) akan menemukan kesimpulan bahwa tasawuf merupakan salah satu ekspresi nyata dari ajaran dasar Islam yang telah menjadi warisan intelektual Islam dari masa klasik disamping tradisi intelektual lain yaitu fiqh, kalam, dan filsafat. Tidak sulit dijumpai ayat-ayat alQuran dan hadis yang mendasari kaum Muslim untuk menjalani hidup melalui jalan mistik/tasawuf. ${ }^{1}$ Dalam perkembangan sejarah umat Islam pola hidup tasawuf bisa

1 QS. Al-Anfal: 17, Nur: 35, al-Baqarah: 115, Ali Imron: 31. dijumpai pada hampir seluruh kawasan Islam, dengan karakteristik yang beragam sebagai manifestasi atas pertemuan ortodoksi Islam dengan peradaban dan budaya lain. Pola hidup tasawuf terus berkembang hingga sekarang lantaran ajaran-ajaran yang disampaikan oleh kaum sufi mengandung ajaran inti dari alQuran, yakni mendekatkan diri kepada Allah. Ajaran ini mengarah kepada suatu perbuatan jiwa yang benar-benar suci sehingga memancar dalam perilaku atau akhlak yang mulia.

Fazlur Rahman dalam menganalisis perkembangan tasawuf menemukan kenyataan bahwa sejak abad kedua Hijriyah 
tasawuf menjadi daya tarik istimewa di kalangan sebagian kaum muslim sebagai reaksi terhadap pola hidup hedonis yang mulai menjangkiti kaum muslim dan pola keberagamaan yang legal-formal para ahli fiqih. ${ }^{2}$ Tasawuf juga cukup mempengaruhi percepatan penyebaran Islam dan proses perkembangan pemikiran Islam melalui ordo-ordo sufi atau tarekat yang sangat kuat dalam memelihara kesinambungan ajaran melalui penyebaran para murid. Jika ada sebagian orang berpendapat bahwa tasawuf sebagai penghambat perkembangan Islam, tentu pendapat ini perlu diuji kembali dalam perjalanan sejarah umat Islam di berbagai wilayah. ${ }^{3}$

Dari literatur sejarah bisa dijumpai sekian banyak ajaran tasawuf yang pernah dipraktekkan oleh para sufi dan menjadi jalan bagi para pendamba perjumpaan dengan Tuhan. Ajaran yang dimaksud adalah mahabbah (Rabi'ah al-'Adawiyah, 713-801 M.), ma'rifah (Zunnun al-Mishri, w. 860 m., Al-Ghazali, 1111 M.), wihdatul wujud (Muhy al-Din Ibn 'Arabi), ittihad (Abu Yazid al-Bustami, w. 874 M), Ana al-Haqq (Husain Ibn Mansur al-Hallaj, 858-922 M.), Insan kamil (Abd al-Karim al Jilli, 1365-1428 M) dan lain sebagainya.

Kerangka yang tepat untuk kajian ini diawali dengan mengemukakan riwayat singkat dalam konteks historis tokohtokoh, kemudian memetik sebagian kecil pandangannya mengenai mahabbah dari Rabi'ah dan ma'rifat dari Zunnun al-Misri dan al-Ghazali. Asumsi yang dikedepankan dalam makalah ini adalah bahwa dalam sebuah peradaban yang plural dan kosmopolit kebenaran mutlak menjadi semakin problematik, yang berimplikasi pada kecenderungan pola penghayatan keagamaan yang bersifat individual.

2 Fazlur Rahman, Islam: Sejarah Pemikiran dan Peradaban, (terj.) M. Irsyad Rafsadie, (Bandung: Mizan, 2017), hlm. 192.

3 Sri Mulyati dkk., Mengenal dan Memahami TarekatTarekat Muktabarh di Indonesia, (Jakarta: Kencana, 2006), hlm. 6-7.

\section{HASIL DAN PEMBAHASAN}

\section{Perkembangan Awal Tasawuf}

Sebagian besar pengamat perkembangan tasawuf menyatakan bahwa praktek tasawuf berasal dari asketisme atau praktek zuhud Nabi dan para sahabatnya. Asketisme yang ditimba dari Al-Quran dan Sunnah pada dasarnya tidak memalingkan diri dari kehidupan masyarakat bahkan asketisme membekali manusia tenaga-tenaga rohaniah sehingga mampu menghadapi dan membimbing umat. $^{4}$ Namun demikian asketisme tersebut berkembang menjadi gerakan yang mengarah kepada "lari dari dunia". Askestisme kemudian mendapat dorongan dari berbagai sisi sehingga semakin menguatkan untuk menjadi satu pola hidup. Pemerhati tasawuf menyatakan perkembangan ini dipengaruhi oleh sejumlah faktor, baik internal maupun eksternal.

Faktor-faktor internal di antaranya adalah pertama, pemahaman secara ekstrem akan isyarat-isyarat al-Qur'an dan Sunnah yang mendorong hidup zuhud. Kedua, revolusi ruhaniah kaum muslimin terhadap kondisi sosio-politik yang ada. Ketiga, penentangan terhadap fiqh dan kalam dan filsafat yang dipandang terlalu formal dan rigid. ${ }^{5}$ Sedangkan secara eksternal tasawuf dipengaruhi oleh ajaran Vedanta Hindu, filsafat gnosis Yunani, asketisme Kristen dan ajaran Persia kuno yang lebih dahulu hidup sebelum agama Islam menyebar ke berbagai wilayah tersebut. $^{6}$

4 Amin Syukur, Zuhud di Abad Modern (Yogyakarta: Pustaka Pelajar, 1987), hlm. 7-8.

5 A. J. Arberry, Pasang Surut Aliran Tasawuf (terj.) Bambang Hearawan) (Bandung: Mizan, 1985), hlm. 35.

6 Amin Syukur, Zuhud ... hlm. 8. Meskipun sebagian besar pengamat tasawuf sepakat dengan faktor-faktor tersebut Hamka memberikan catatan kritis mengenai pengaruh eksternal ini. Bahkan Hamka cenderung menolak faktor tersebut sambil menunjukkan orisinalitas ajaran tasawuf dari al-Qur'an dan hadis. Lihat Hamka, Tasawuf: Perkembangan dan 
Secara lebih komprehensif perkembangan awal tasawuf dikemukakan oleh Danner, bahwa ada sejumlah peristiwa yang berlansung pada aba ketiga hijriyah yang kesemuanya membuat tasawuf menguat. Yaitu (1) kecenderungan mencampur asketisme dengan dengan tradisi zuhud; (2) semakin mantapnya aliran-aliran yurisprudensi eksoterik; (3) pernyataan-pernyataan kaum Syiah mengenai kemaksuman para Imam; (4) munculnya filsafat Islam; (5) meningkatnya formalisme ahli-ahli hukum; dan (6) tuntutan untuk memastikan bahwa pesan integral wahyu yang di dalamnya mengandung dorongan untuk mengambil jalan tasawuf. ${ }^{7}$

Selama dua abad pertama, Sufisme masih merupakan fenomena individual dan spontan. Dengan berkembangnya ilmu hukum (fiqih) dan teologi Islam, sufisme berkembang menjadi pranata dengan daya tarik yang luar biasa. Seiring dengan dinamika intelektual dan politik umat Islam pada abad kedua, tasawuf juga mengalami perubahan pada konsepkonsepnya. Perkembangan ini ditandai adanya perhatian para sufi pada hal-hal yang esoteris dan agak mengabaikan dimensi agama yang eksoteris seperti figh dan filsafat. Syari'at terkesan diabaikan oleh para sufi yang telah mencapai kenikmatan pada tingkat hakekat. Dalam perkembangan selanjutnya para sufi tidak puas jika hanya mencapai maqam mahabbah dan ma'rifah, tetapi mereka menyatakan bahwa puncak tasawuf adalah mencapai kesatuan dengan Tuhan wahdat al-wujud. Perkembangan terakhir ini karena para sufi terpengaruh oleh filsafat dan gnosis dari Yunani.

Ketika kalam, filsafat dan fiqh mulai menapak kepada perkembangan dan gerakan-gerakan pembukuan, maka tasawuf juga mulai merumuskan metode dan konsep-konsepnya sendiri, yang berbeda dengan filsafat, figh dan kalam. Oleh karena itu menurut Ibn Khaldun, ketika

Pemurniannya (Jakarta: Pustaka Panjimas, 1984), hlm. 55-66.

7 Victor Danner, "Perkembangan Awal Tasawuf" dalam Seyyed Hossein Nasr (ed.), Esiklopedi Tematis Spiritualitas Islam: Fondasi, (ter. Rahmani Astuti), (Bandung: Mizan, 2003), hlm. 338. di antara para sufi telah menulis dengan sikap rendah hati dan introspeksi tentang apa yang perlu dilakukan dan ditinggalkan, ilmu tasawuf merupakan ilmu yang tersusun secara mandiri. ${ }^{8}$

Selanjutnya perkembangan tasawuf dapat dikelompokkan ke dalam dua kecenderungan. Pertama, aliran tasawuf yang moderat, artinya tasawuf yang dibangun dengan selalu merujuk kepada al-Quran dan Sunnah. Tasawuf dalam kategori ini dipenuhi dengan ciri-ciri dekat dengan syari'at dan ajaran moral yang tinggi. Kedua, aliran para sufi yang terpesona dengan kehidupan fana. Dalam aliran ini muncul pengakuan-pengakuan dan istilah yang menggambarkan hubungan antara manusia dengan Tuhan, misalnya hulul, ittihad, wahdatul wujud, ma'rifah dan mahabbah. Kecenderungan tasawuf ini disamping banyak dipengaruhi oleh perkembangan corak tasawuf yang pertama juga dipengaruhi oleh perkembangan filsafat rasionalistik dan filsafat emanasi tentang kesatuan Wujud. ${ }^{9}$

Dalam perkembangan berikutnya kecenderungan tasawuf yang pertama lazim disebut tasawuf akhlaki, sedangkan kencenderungan yang kedua sering disebut tasawuf falsafi. ${ }^{10}$ Secara kronologis tipologi aliran tasawuf akhlaki untuk menunjukkan perkembangan tasawuf pada abad pertama Hijriyah dan awal abad kedua Hijriyah. Tasawuf falsafi untuk menunjukkan perkembangan tasawuf pada akhir abad kedua sampai keempat $H$. Pada abad keliam dan keenam $\mathrm{H}$ tasawuf akhlaki kembali menemukan kegemilangannya. ${ }^{11}$

8 Ibnu Khaldun, Muqaddimah (Jakarta: Pustaka Firdaus, 1986), hlm. 136.

9 Kaustar Azhari Noer, Ibnu 'Arabi: Wahdat al-Wujud dalam Perdebatan, (Jakarta: Paramadina, 1997) hlm. $1-2$.

10 Salah seorang yang berpendapat dalam masalah ini adalah Nurcholish Madjid. Dalam banyak karyanya ia menyebut tasawuf al-Ghazali adalah tasawuf falsafi. Nurcholish Madjid, Kaki Langit Peradaban Islam (Jakarta: Paramadina, 1997), hlm. 79-86. Sedangkan Kautsar Azhari Noer menempatkan al-Ghazali dalam jajaran tasawuf Sunni. Lihat Kaustar Azhari Noer, loc. cit.

11 Pembagian berdasarkan periodesasi waktu demikian tidak sepenuhnya bisa dibenarkan. Karena tidak semua sufi yang hidup pada periode itu menggunakan corak yang sama. Akan tetapi untuk kepentingan makalah ini 
Sedangkan tasawuf falsafi -meskipun tidak hilang sama sekali di Baghdad-berkembang di wilayah Ishafan pada masa dinasti Syafawid. ${ }^{12}$ Mempelajari perkembangan tasawuf tidak bisa meninggalkan perkembangan pemikiran Islam lainnya, seperti filsafat, fiqh dan kalam. ${ }^{13}$

\section{Cinta Tuhan dari Rabi'ah al- 'Adawiyah}

Perkembangan tasawuf pada akhir abad kedua telah mengambil bentuk yang berlainan dengan tasawuf pada masa shahabat dan tabi'in. Mengapa terjadi perbedaan kecenderungan? Telah disebutkan di muka bahwa pola hidup zuhud pada awalnya hanya merupakan ekspresi bentuk lain ibadah dalam arti fiqhiyah. Kemudian para fuqaha' berusaha merumuskan konsep-konsep ajaran agama hanya tidak menyentuh kedalam batin ajaran Islam. Sikap sufi bukan hanya tidak menyukai keadaan seperti itu tetapi juga menjadi oposisi terhadap pemerintah yang berkuasa. ${ }^{14}$

Menurut Javad Nurbakhs, Rabi'ah al'Adawiyah termasuk sufi yang hidup pada periode akhir abad kedua dalam sejarah perkembangan tasawuf. Pada periode ini unsur-unsur dalam tasawuf agak berbeda dengan kecenderungan pada periode sebelumnya. Pada periode pertama para sufi mengajarkan untuk takut kepada Allah dengan takut atas siksanya dan mengharap kebahagiaan di surga. Pada periode kedua para sufi secara filosofis beralih kepada unsur-unsur isq atau kerinduan dan

pembagian tersebut masih diperlukan. Pada akhir abad kedua Hijriyah mulai terjadi pergeseran pandangan para sufi, misalnya tampak pada diri Rabi'ah alAdawiyah.

12 Seyyed Hossein Nasr, Tasawuf: Dulu dan Sekarang (ter.) Abdul Hadi WM, (Jakarta: Pustaka Firdaus, 1985), hlm. 63.

13 Fazlur Rahman memberikan penjelasan cukup menarik tentang hal ini. Ia melihat bahwa perkembangan tasawuf, baik yang sunni maupun falsafi, merupakan rangkaian yang tidak terpisahkan dengan perkembangan pemikiran lain, termasuk perkembangan politik. Lihat Fazlur Rahman, Islam., hlm. 200.

14 Nurcholish Madjid, Islam, Doktrin dan Peradaban (Jakarta: Paramadina, 1995), hlm. 254. mahabbah atau cinta kepada Allah ditambah kepada asketisme dan paktek zuhud yang luar biasa. ${ }^{15}$

Dalam konteks perkembangan religiopolitik Rabi'ah hidup pada masa akhir pemerintahan Umayyah dan pemerintahan Abbasyiyah mulai menapaki puncak kekekuasaan. Ilmu-ilmu tradisional Islam juga mencapai tahap yang relatif mapan dan menemukan kodifikasi yang menjadi sumber perilaku kaum muslim. Umat Islam mulai sampai pada masa kesepakatan tentang bagian-bagian yang sebelumnya tampak ambigu lantara pengamalan ajaran Islam di kalangan kaum muslim mengandalkan ingatan.

Rabiah Al-Adawiyah dikenal juga dengan nama Rabi'ah Basri adalah seorang sufi wanita yang dikenal karena kesucian dan kecintaannya terhadap Allah. Rabi'ah merupakan klien (Mawlat) dari klan AlAtik suku Qays bin 'Adi, dimana ia terkenal dengan sebutan al-Qaysyah. Ia dikenal sebagai seorang sufi wanita yang zuhud, yaitu tidak tertarik kepada kehidupan duniawi, sehingga ia mengabdikan hidupnya hanya untuk beribadah kepada Allah. Rabiah diperkirakan lahir antara tahun 713-717 Masehi, atau 95-99 Hijriah, di kota Basrah Irak dan meninggal sekitar tahun $801 \mathrm{M} / 185 \mathrm{H}$. Nama lengkapnya adalah Ummu al-Khair Rabî’ah binti Ismâ'îl al-Adawiyyahal-Qishiyyah. Rabiah merupakan sufi wanita beraliran Sunni pada masa dinasti Umayyah. Rabi'ah Adawiyah menjadi pemimpin dari murid-murid perempuan dan zahidah, yang mengabdikan dirinya untuk Tuhan. Rabi'ah Al-Adawiyah dijuluki sebagai The Mother of the Grand Master atau Ibu Para Sufi Besar karena kezuhudannya. Ia juga menjadi panutan para ahli sufi lain seperti Ibnu al-Faridh dan Dhun Nun Almisri.

Rabi'ah memang tidak mewarisi karyakarya sufistik, termasuk syair-syair Cinta Ilahinya yang kerap ia senandungkan.

15 Javad Nurbakhsh, Wanita-wanita Sufi (Bandung: Mizan, 1996), hlm. 2-3. Ada sebuah buku sederhana yang dapat mengantarkan kita kepada pengetahuan tentang konsep mahabbah dari Rabi'ah al-Adawiyah adalah Asfari Mahabbah dalam Tasawuf Rabi'ah al-Adawiyah, (Yogyakarta: Bentang Budaya, 1998). 
Namun begitu, Sya'ir-sya'ir sufistiknya justru banyak dikutip oleh para penulis biografi Rabi'ah, antara lain J. Shibt Ibnul Jauzi (w. 1257 M) dengan karyanya Mir'at az-Zaman (Cermin Abad Ini), Ibnu Khallikan (w. $1282 \mathrm{M})$ dengan karyanya Wafayatul A'yan (Obituari Para Orang Besar), Yafi'I asySyafi'i (w. 1367 M) dengan karyanya Raudl ar-Riyahin fi Hikayat ash-Shalihin (Kebun Semerbak dalam Kehidupan Para Orang Saleh), dan Fariduddin Aththar (w. 1230 M) dengan karyanya Tadzkirat al-Auliya' (Memoar Para Wali).

Rabi'ah termasuk dalam golongan wanita sufi pilihan yang mengungguli hampir semua tokoh sufi di zamannya dalam menempuh jalan menuju Allah. Jika seorang penulis hendak mengutip namanama sebagian wali sufi besar, maka tak pelak lagi nama Rabi'ah pasti akan disebut. Keunggulan dalam ketaqwaan, ma'rifat dan mahabbah, telah menjadikannya sebagai simbol kewalian di kalangan kaum sufi wanita. Perasaan yang biasa disuarakan para sufi pada periode kedua adalah bahwa ibadah yang mereka lakukan kepada Allah bukanlah disebabkan oleh takut pada sisksa neraka dan berharap memperoleh ganjaran surga, melainkan semata-mata lantaran cinta dan ibadah yang memang berhak diperoleh Allah. Dengan penuh gelora Rabi'ah mengaku:

"Aku bersumpah demi keagungan-Mu Bahwa aku beribadah kepada-Mu

bukan lantaran mengharap surga atau takut siksa neraka.

Aku beribadah kepada-Mu semata demi keluhuran dan keagunganMu."

Margaret Smith menyitir syair Rabi'ah:

"Tuhanku,

jika aku menyembah pada-Mu lantaran takut api neraka,

bakarlah aku di dalamnya.

Dan jika aku menyembah Engkau lantaran mengharap pahala surga, jauhkanlah aku daripadanya.

Akan tetapi jika aku menyembah pada-Mu lantaran Dirimu jangan Kau sembunyikan keindahan-Mu yang Abadi". ${ }^{16}$

Perasaan cinta yang meresap ke dalam lubuk hati Rabi'ah menyebabkan ia mengorbankan hidupnya semata-mata untuk beribadah kepada Allah. Cinta Rabi'ah kepada Allah merupakan cinta suci, murni dan sempurna seperti yang disenandungkan dalam syairnya:

"Aku mencintaimu dengan dua cinta, Cinta karena diriku dan cinta karena diri$\mathrm{Mu}$

Cinta karena diriku,

adalah keadaanku senantaiasa mengingat$\mathrm{Mu}$

Cinta kerana diri-Mu,

adalah lantaran keadaan-Mu menyingkapkan tabir hingga Engkau kulihat

Baik untuk ini untuk itu pujian bukanlah bagiku,

bagi-Mulah pujian untuk semuanya,

Buah hatiku hanya Engkau lah yang kukasihi,

Beri ampunilah pembuat dosa yang datang kehadiratMu,

Engkaulah harapanku, kebahagiaanku, dan kesenanganku,

Hatiku enggan mencintai selain Engkau. ${ }^{17}$

Hati Rabi'ah telah dipenuhi oleh perasaan cinta kepada Allah, sehingga tidak menyisakan sedikitpun untuk mencintai dan membenci yang lain termasuk Nabi Muhammad. Dari syair di atas Rabi'ah merupakan pelopor yang memperkenalkan cinta ajaran mistik dalam Islam, yakni terbukanya tabir penyekat alam ghaib sehingga sang sufi bisa mengalami menyaksikan dan berhubungan langsung dengan dunia ghaib dan Tuhan. Dengan cita rasa ajaran mistik ini Rabi'ah berusaha mengalihkan secara drastis tujuan hidup umat Islam.

16 Margareth Smith, Reading from the Mystics of Islam (London: Moutan, 1950), hlm. 12.

17 Hamka, Tasawuf...,. hlm. 80. Syair ini merupakan syair yang paling sering dikutip oleh peneliti dan pengamat tasawuf. Dari syair inilah Rabi'ah di tempatkan sebagai pencetus konsep mahabbah dalam tasawuf. 
Ciri-ciri watak sufisme serta tujuan utamanya yang menjadi inti ideal ajaran tasawuf memang telah diungkapkan oleh Rabi'ah. Bahkan ruh utama pendorong kehidupan batin para sufi juga telah digelar secara indah dan jitu oleh Rabi'ah, yaitu cinta rindu pendorong kegandrungan untuk bertemumuka atau bahkan bersatu dengan Tuhan. Cinta rindu atau syauq yang menimbulkan kegelisahan hati antara takut dan harap yang memuncak dalam penghayatan sakar (mabuk cinta) adalah ruh kehidupan batin para sufi. Mahabbah pada Tuhan dan bentuknya yang murni dan bahkan ekstrem emosional ini tentu menjadikannya merendahkan apa saja selain Allah. Misalnya ketika Rabi'ah ditanya apakah ia juga cinta kepada Nabi Muhammad. Rabi'ah menjawab "Dalam hatiku telah penuh cinta kepada Allah sehingga tidak ada lagi ruang yang tersisa untuk mencintai yang lain. Inilah mahabbah dalam ajaran Rabi'ah. ${ }^{18}$

Rabi'ah telah sampai ke station mahabbah. ${ }^{19}$ Ia telah melihat Tuhan dengan hati nuraninya. Ia telah sampai ke station yang menjadi idaman kaum sufi. Menurut Abd al-Hakim Hasan sebagaimana dikutip oleh Simuh, Rabi'ah telah memulai membukakan konsep cinta kepada Allah menurut ajaran tasawuf yang sesungguhnya. Konsep ini belum pernah ada pada tasawuf sebelum masa Rabi'ah. Dalam perkembangan selanjutnya konsep ini kemudian juga diikuti oleh para sufi selanjutnya. ${ }^{20}$ Ungkapan di atas menunjukkan adanya perbedaan yang mendasar antara ahli syariah (figh) sebagai pencari pahali surgawi dengan sufi sebagai pencari Tuhan.

Rabiah menempatkan cinta di pusat dan membantu melahirkan tradisi panjang "Sufi mabuk Allah". Amalan spiritualnya dimulai dengan ibadah yang dikenal dalam Islam dan menambhkan ibadah sunnah lainnya. Namun tidak sedikit tradisi ini kemudian diikuti dengan cara yang salah, antara lain

18 Simuh, Tasawuf dan Perkembangannya dalam Islam (Jakarta: Rajawali Pers, 1996), hlm. 32.

19 Harun Nasution, "Tasawuf" dalam Budhy Munawar Rahman (Ed.), Kontekstualisasi Doktrin Islam dalam Sejarah (Jakarta: Paramadina: 1995), hlm. 168.

20 Simuh, Tasawuf.., hlm. 36. dengan bernyanyi-nyanyi hingga mencapai ekatase di luar kesadaran manusia normal. Mungkin perwujudan luar biasa cinta yang ditemukan dalam diri Rabi'ah harus dianggap sebagai kompensasi spiritual bagi meningkatnya legalisme eksoterik yang mendorong motivasi perbuatan baik yang diperhitungkan untuk dipertukarkan dengan dengan pahala-pahala di akhirat dan rasa takut akan siksaan dan bukan karena cinta kepada Allah, yang menjadi motivasi di balik perbuatan-perbuatan semacam itu.

\section{Ma'rifah: Puncak Ektase Zunnun al- Mishri dan Al-Ghazali}

Tidak lama setelah meninggalnya Rabi'ah, lahir Abdul Faidh Zunnun alMishri, ${ }^{21}$ seorang tokoh sufi besar di abad ketiga Hijriah. Beliau, yang memiliki nama lengkap Abu Al-Faidh Tsauban bin Ibrahim Al-Mishri, dilahirkan di Akhmim, sebuah kota kuno di tepi timur Sungai Nil dan dataran tinggi di Mesir, pada tahun $796 \mathrm{M}$ $(180 \mathrm{H})$. Seorang sufi besar yang menjadi pencetus ma'rifah dalam pengalaman sufi. Ma'rifah adalah anugerah Tuhan kepada sufi yang dengan akhlas dan sungguh-sungguh mencintai Tuhan. Karena ikhlas dan cinta itulah Tuhan membukakan tabir dari pandangan sufi, dan terbukanya tabir itu menjadikan sufi dapat meneriman cahaya yang dipancarkan oleh Tuhan.

Dari segi bahasa, $M a^{\prime}$ rifah berasal dari kata 'arafa, ya'rifu, 'irfan dan ma'rifah yang artinya mengetahui atau pengalamanDan apabila dihubungkan dengan pengalaman tasawwuf, maka istilah ma'rifah di sini berarti mengenal Allah ketika Sufi mencapai suatu maqam dalam tasawuf. Kemudian istilah ini dirumuskan definisinya oleh beberapa Ulama Tasawwuf, antara lain Mustafa Zahri mengemukakan salah satu pendapat Ulama' Tasawuf yang mengatakan: "Ma'rifah adalah ketepatan hati (dalam memercayai hadirnya) wujud yang wajib adanya (Allah) yang menggambarkan segala kesempurnaan." Imam Al-Qusyairy

21 Dalam catatan Hamka, Zunnun berasal dari Naubah, sebuah desa di antara Mesir dan Sudan. Ia hidup tidak lama setelah Rabi'ah. Oleh karena itu ajaranajaran tasawufnya masih dipengaruhi dengan konsep Rabi'ah. 
mengemukakan pendapat Abdur Rahman bin Muhammad bin Abdillah yang mengatakan"Ma'rifah membuat ketenangan dalam hati, sebagaimana ilmu pengetahuan membuat ketenangan (dalam akal pikiran). Barang siapa yang meningkat ma'rifahnya, maka meningkat pula ketenangan (hatinya)."

Ketika Zunnun ditanya bagaimana ia memperoleh ma'rifah, ia menjawab: "Aku melihat dan mengetahui Tuhan dengan Tuhan, dan sekiranya tidak karena Tuhan aku tidak melihat dan tidak tahu Tuhan". Yang dimaksud Zunnun adalah bahwa ia memperoleh ma'rifah karena kemurahan Tuhan. Sekiranya Tuhan tidak membukakan tabir dari mata hatinya, ia tidak akan melihat Tuhan. Sebagaimana disebut dalam literatur tasawuf, sufi berusaha keras mendekatkan diri dari bawah dan Tuhan menurunkan rahmat-Nya dari atas.

Menurut Zunnun paham ma'rifah ada tiga macam, yaitu (1) pengetahuan orang awam bahwa Tuhan Esa diketahui melalu ucapan. (2) Pengetahuan ulama bahwa Tuhan diketahui dengan logika, dan (3) pengetahuan sufi bahwa Tuhan Esa diketahuidenganperantaraanhatisanubari. ${ }^{22}$ Orang yang percaya adanya Tuhan hanya mengikuti para pendahulunya, memang demikianlah ajaran yang diterima. Para filosof dan mutakallimin mencari Tuhan dengan perjalanan akalnya. Dengan bantuan akalnya seorang filosof mempercayai adanya Tuhan tetapi belum tentu dirasakan lezatnya pengetahuan itu. Sedangkan orang sufi mencari Tuhan dengan pedoman cinta. Yang lebih diutamakan ilham, faidh dan kasyf. ${ }^{23}$

Ma'rifah yang sesungguhnya adalah ma'rifah yang dicapai oleh orang-orang yang dengan hatinya melihat Tuhan. Akal dan indera tidak akan mampu mencapai kepada puncak ma'rifah sebagaimana yang dirasakan oleh para sufi. Nicholson, yang mengagumi metode yang dikembangkan oleh Zunnun, menyatakan bahwa Zunnun al-Mishri dalam spekulasi-spekulasi mistiknya mencirikan dia sebagai

22 Taufik Abdullah dkk., Ensiklopedi Islam (Jakarta: PT. Ichtiar Baru Van Hoeve, 1993), hlm. 130.

23 Hamka, Tasawuf: Perkembangan dan Pemurniannya (Jakarta: Pustaka Panjimas, 1986), hlm. 101. bapak theosophy muslim. Lebih lanjut ia menyatakan bahwa secara logika ajaran ma'rifah Zunnun Al-Mishri membatalkan berlakunya setiap nilai moral dan hukum agama. Dalam pengahayatan para ahli ma'rifah tidak ada artinya pahala dan siksa Tuhan, dan tidak ada ukuran benar dan salah. Bagi kaum 'arifin ayat-ayat suci yang tersurat telah terhapus oleh hubungan langsung dan intim dengan Tuhan. ${ }^{24}$

Secara umum ia diakui sebagai sufiyang memperkenakan gagasan ma'rifah kedalam tasawuf, meskipun ajaran ma'rifah ini dapat dilacak dari para filosof pendahulunya. Di dalam beberapa sya'irnya Zunnun menggunakan ungkapan-ungkapan mesra sejatai sebagaimana yang telah dilakukan oleh Rabi'ah.

Abu Hamid Muhammad Ibn Muhammad al-Tusi al-Syafi'i al-Ghazali (1085-1111 M.) hidup pada abad V Hijrah, di mana masa umat Islam berada dalam kondisi ketidakpastian. Pertentangan antargolongan semakin luasa dan gerakan bathini terus berkembang. Sementara golongan Syi'ah memegang kekuasaan di Bagdad meskipun belum mendapat legitimasi kaum sunni, kemudian kembali jatuh ke tangan kelompok Sunni. ${ }^{25}$

Di samping situasi politik hangat, masa itu diwarnai oleh pertentangan golongan, aliran dan paham. Setiap golongan mempertahankan keberadaannya secara fanatik, menuduh kafir atau bid'ah golongan lain yang tidak sependapat dengan pemikirannya. ${ }^{26}$ Ada aliran yang berdiri atas paham salah. Ada lagi yang membangun atas dasar keagamaan sesuai dengan interpretasinya sendiri terhadap alQur'an. Ada juga aliran yang membangun pahamnya dengan mencampuradukkan pengertian al-Quran dengan ajaran asing. Ini akibat masuknya filsafat Yunani dan paham-paham lain. Tasawuf Islam juga dipengaruhi oleh paham mistik India,

24 Reynold A. Nicholson, The Mystics of Islam (London: Routledge and Kegan Paul, 1963), hlm. 86-87.

25 Victor Said Basil, Al-Ghazali Mencari Ma'rifah (terj.) Ahmadi Thaha (Jakarta: Pustaka Panjimas, 1990), hlm. 2.

26 Montgomery Watt, Kejayaan Islam: Kajian Kritis dari Tokoh Orientalis (terj.) Hartono H. (Yogyakarta: Tiara Wacana, 1990), hlm. 196. 
sementara ilmu Kalam dipengaruhi oleh filsafat. ${ }^{27}$

\section{Al-Ghazali}

mengelompokkan golongan-golongan itu menjadi tiga. Pertama, golongan yang menggunakan dasar-dasar agama. Yang termasuk dalam golongan ini adalah pra sufi dan kaum ta'limi (pengikut Ali). Kedua, aliran yang menggunakan akal bebas, seperti para filosof. Filosof mengerahkan daya akal untuk memikirkan masalah fisik dan metafisik, bakan untuk memikirkan keberadaan Tuhan. Ketiga aliran yang menggunakan akal terikat, yaitu kaum mutakallimin, yang mengatakan bahwa kemampuan akal terbatas pada ilmu-ilmu kemanusiaan. Sedangkan di bidang metafisika akal tidak dapat berperan. ${ }^{28}$

Suasana chaos pada masa itu menyuburkan sekelompok orang yang menganut paham skeptisisme. Tidak sedikit orang yang hanyut dalam paham skeptis karena banyaknya sekte dan terbatasnya akal dalam memahami realitas Tertinggi. Dalam karyanya Al-Munkidh min al-Dhalal al-Ghazali tidak bisa menutupi keresahan dirinya ketika ia menjadi seorang mutkallim dan seorang filosof sebelum akhirnya ia memilih jalan dzauq dan kasyf untuk memperoleh kebenaran yang sesungguhnya. ${ }^{29}$

Bagi al-Ghazali, seseorang dapat mencapai ma'rifah apabila ia telah melakukan perjalanan ke seluruh penjuru lautan ilmu, baik itu filsafat, kalam, figh atau bahkan ilmu-ilmu yang ditemukan orang-orang nonmuslim. Al-Ghazali berpendapat bahwa akal manusia tidak mungkin menemukan hakekat keimanan melalui ilmu yang dimilikinya atau ilmu yang diupayakan. Untuk mengetahui hakekat keimanan akal tidak dapat berdiri sendiri, melainkan harus dibantu oleh ilmu syari'at yang bersumber dari al-Qur'an. Al-Ghazali menulis:

"Mata tidak mungkin melihat warna tanpa cahaya. Itu selalu bersamaan dan tidak pernah kosong, apakah warna itu ditangkap oleh mata atau pun dipantuli sinar matahari. Mata tidak bisa mengakap

27 Victor, Al-Ghazali..., hlm. 3.

28 Al-Ghazali, Pembebas dari Kesesatan (terj.) Abdullah Bin Noer (Jakarta: Tinta Mas, 1980), hlm. 8.

29 Ibid., hlm. 12. warna dalam kegelapan, sebab warna hanya dapat memalui pantulan cahaya, lalu dikatakan kepadanya 'kesahihan' ketika dijelaskan tentang tangkapan mata yang bersamaan dengan pemantulan cahaya." 30

Di samping syariat al-Ghazali masih menggunakan dzauq (cita rasa batiniah yang amat halus) yang dapat terwujud melalui latihan akal yang berdasar pada syari'at. Lebih dari itu qalb (hati) bagi AlGhazali adalah sarana paling penting untuk mencapai ma'rifah. Al-Ghazali menulis: "Adapun untuk mencapai ma'rifatullah hanya dapat dilakukan melalui penghayatan qalb. Bukannya anggota badan lain. Maka hati adalahyang alim terhadap Allah dan dia pula yang bertaqarrub kepadaNya. Hati pula yang menuju kepada Allah dan pembuka tabir untuk menghayati alam ghaib yang berada di sisi Allah." 31

Kesimpulan al-Ghazali di atas merupakan hasil perjalanan intelektualnya yang tidak kenal lelah. Sebelum menarik kesimpulan dan disebarkan ke seluruh ummat al-Ghazali telah memeriksa berbagai jalan mencari keberan. Selanjutnya mengatakan:

"Akhirnya Allah berkenan menyembuhkan penyakit ragu yang ada dalam diriku. Pikiran menjadi sehat dan berkesinambungan kembali. Dengan amat yakin dan aman dapat menerima segala pengertian-pengertian awali dan akal. Semua itu terjadi tidak dengan mengatur alasan atau menyusun keterangan, melainkan dengan Nur ilahi yang dipancarkan dalam hatiku. Nur ini adalah kunci pembuka sebagian besar dari ilmu ma'rifah." ${ }^{32}$

Konsep-konsep Al-Ghazali baik tengang mahabbah maupun ma'rifah banyak dipengaruhi oleh sufi pendahulunya Rabi'ah dan Zunnun. Dalam satu kesempatan ia mengutip dan menyetuji syair-syair cinta rindu Rabi'ah. Pengaruh demikian tampak pada syair berikut setelah al-Ghazali mengutip Rabia'ah menyatakan: "Lezat datang setelah ada cinta. Cinta timbul dari ma'rifah. Ma'rifah timbul setelah hati bersih

30 Al-Gazali, Mutiara Ihya' Ulumuddin (terj.) Ru'san (Jakarta: Mulia, 1963), hlm. 248.

31 Ibid., hlm. 340.

32 Al-Ghazali, Pembebas dari Kesesatan, hlm. 12. 
oleh renungan fikiran yang murni berzikir terus menerus kepada Allah"33

Harun Nasution dalam mengamati ajaran tasawuf Al-Ghazali menyimpulkan bahwa kata ma'rifah mengandung arti pengetahuan. Maka ma'rifah dalam tasawuf berarti pengetahuan yang diperoleh langsung dari Tuhan melalui kalbu. Pengetahuan ini disebut 'ilm laduni. ${ }^{34}$ Ma'rifah berbeda dengan ilmu, karena ilmu diperoleh malalui akal saja. Dalam pandangan Al-Ghazali pengetahuan yang diperoleh melalui kalbu lebih sempurna dari pengetahuan yang diperoleh dengan akal. Menurut catatan Simuh, rumusan alGhazali mengenai ma'rifah lebih sederhana dan jelas mudah dimengerti. Al-Ghazali merupakan juru bicara yang piawai di kalangan sufi dalam mendamaikan konsep-konsep tasawuf yang dipandang menyimpang dari ajaran Islam hingga bisa diterima oleh umat Islam pada umumnya. ${ }^{35}$

Al-Ghazali melakukan reorientasi terhadap perkembangan sufisme yang mengarah kepada teosofi. Penyelidikan filosofis tentang hakikat Tuhan yang dilakukannya tidak menghasilkan apaapa, ia pun beralih kepada Sufisme untuk mencari cara lain dalam memperoleh pengetahuan ini. Ia juga tidak berharap memperoleh pengetahuan ghaib yang luar biasa. Tujuannya adalah untuk hidup dalam kebenaran iman dan untuk menguji kebenaran tersebut dengan metode eksperiensial sufi. Pengujiannya telah memperkuat imannya dengan kesimpulan: pertama bahwa hanya dengan kehidupan batin sajalah iman sejati dapat diperoleh dan (kedua) sufisme tidak punya muatan atau objek kognitif selain iman. Karena itu Al-Ghazali menyangkal pretensi-pretensi mistisisme teosofis dan menuding para penganutnya telah larut dalam pseudoektase.

\section{Catatan-catatan Reflektif}

Tasawuf sebagai gerakan pencari Tuhan secara langsung sejak awal pertumbuhannya bisa dikatakan sebagai

33 Al-Ghazali, Cinta dan Bahagia (terj.) Abdullah Bin Nuh (Jakarta: Tinta Mas, 1984), hlm. 14.

34 Harun Nasution, Tasawuf.., hlm 170.

35 Simuh, Tasawuf..., hlm. 124. gerakan protes. Kaum sufi tidak puas menerima keterangan dan petunjuk wahyu, ingin langsung bertemu dengan Tuhan. Seolah para sufi ingin mendapat wahyu tersenidiri dari Tuhan. Pencapaian mahabbah dan ma'rifah sebagai diuraikan di atas menunjukkan bahwa wahyu dan syari'at sedikit banyak mengganggu hubungan langsung antara manusia dengan Tuhan. Surga dan neraka tidak begitu penting bagi para sufi atau kurang fungsinya.

Rabi'ah dengan ajaran dua macam cintanya telah mengubah "cinta" menjadi cintarindu, berzikir pada Allah dan melupakan segalanya. Al-Quran memerintahkan umat Islam untuk menuntut kebahagiaan dan kebesaran kampung akherat dengan ridha Allah, tanpa lupa memperebutkan kenikmatan dunia. Rabi'ah dengan tasawufnya memandang tujuan hidup mencari akherat itu adalah tabir yang menyesatkan. Ibadah mengharapkan pahala surga dinilai kurang ikhlas, dihinanya sebagai pencari laba pahala atau ganti rugi. Demikian pula Islam, sebagai agama zikir dan pikir untuk beramal dengan etos kerja untuk membangun dunia demi kemajuan peradaban umat manusia, oleh Rabi'ah dengan tasawufnya diubah jadi agama zikir dan merenung.

Adapun mengenai masalah cinta pada Allah dengan RasulNya, Islam memang menekankan wajibnya mencintai Allah dan Rasul melebihi cinta kepada diri sendiri dan segala apa saja. Rabi'ah memperkenalkan konsep cinta yang "emosional", sehingga tidak ada lagi sisi-sisi hidup ini untuk mencintai selain Tuhan. Namun demikian bukankah Islam juga menganjurkan agar segala sesuatu terlebih dahulu dicerna secara rasional? Termasuk di dalamnya adalah bahwa cinta Islam adalah cinta yang rasional.

Pada hemat penulis kebaradaan Zunnun al-Mishri tidakjauh berbeda dengan Rabi'ah dalam merumuskan konsep-konsep ajaran tasawufnya. Bahkan sebenarnya agak sulit untuk membedakan konsep yang dikedepankan oleh Zunnun. Sebagian orang menyatakan konsep Zunnun adalah hampir sama dengan konsep mahabbah. Hanya saja yang lebih menonjol adalah kosepnya tentang ma'rifah. 
Dilihat dari jenis-jenis karyanya, terutama pada usia 50 tahun, tampak bahwa al-Ghazali sosok sufi yang haus akan pencarian ma'rifah. Sekurang-kurangnya ada tiga alasan yang mendorong al-Ghazali memburu ma'rifah. Pertama ia ingin menjadi seorang guru yang profesional untuk menghidupi dirinya. Namun ketika cita-cita itu tercapai semakin menimbulkan hasrat untuk mempelajari ilmu lebih dalam lagi. Karena itu ia pergi ke Naisbur lalu ke Bagdad untuk memenuhi keinginan itu. Kedua, al-Ghazali menganggap dirinya shahib alrisalah (pengemban misi suci), yang bertugas membangun dan menghidupkan kembali ruh agama. Untuk itu ia mengahantam setiap yang membahayakan akidah dan keimanan seseorang. Ini didorong oleh keinginannya untuk membela agama dan menjauhi bid'ah sebagai akibat dari filsafat. Ketiga, dalam berbagai karyanya al-Ghazali adalah seorang yang memiliki watak semangat untuk mengetahui hakekat kebenaran. Oleh karena itu ia suka pindah dari satu tempat ke tempat lain. Dari satu jabatan ke jabatan yang lain, meskipun akhirnya ia kembali mendalami ilmu.

Sebagaimana telah disinggung di muka bahwa al-Ghazali pernah menjadi seorang "skeptis" dan sikapnya itu tidak hanya dimilkinya sendiri. Al-Ghazali menyatakan bahwa jika ucapan dan tulisan yang lontarkan itu hanya membuat ragu maka sebenarnya itu hal wajar dan bahkan bermanfaat. Barang siapa yang tidak ragu berarti ia tidak berpikir. Barang siapa yang tidak berpikir berarti tidak melihat. Orang yang tidak melihat berarti dalam kegelapan. Secara lebih jelas dapat dikatakan bahwa keraguan adalah puncak keyakinan.

Pada pertengahan abad ke-11 kaum muslim berkerja keras pada tiga proyek budaya di luar politik, diupayakan secara berturut-turut oleh ulama-teolog, filosofilmuwan dan kaum mistik sufi. Masingmasing berjuang menguraikan doktrin dan hukum Islam secara penuh, dan mengungkapkan pola dan prinsip alam semesta, dan mengembangkan sebuah teknik mencapai kesatuan pribadi dengan Allah. Ketiga kelompok itu tampak tumpang tindih tetapi secara keseluruhan mereka menarik kearah saling bersaing, dan ketidakpastian intelektual mereka memiliki taruhan politik yang tinggi. ${ }^{36}$ Berbagai perbedaan paham keagamaan, filsafat dan politik mendorong al-Ghazali berinisiatif untuk mendamaikannya. Akan tetapi ia menghadapi berbagai kesukaran dan rintangan. Dalam kondisi demikian, ia terperangkap oleh lingkaran kontradiktif yang berwal tapi tanpa akhir. Kepada kontradiksi-kontradiksi inilah skeptisisme, kepentingan dan rasa sakitnya dikaitkan, sebagaimana yang telah diuraikan dalam buku Al-Munkidh min al-Dhallal.

\section{SIMPULAN}

Dari uraian di atas dapat dikemukakan beberapa hal yang penting. Pertama, fakta sejarah menunjukkan bahwa dinamika internal dan esternal umat Islam dalam membangun peradaban sangat berpengaruh terhadap perkembangan tasawuf, baik dari segi geografis maupun dari segi ajaran. Di satu pihak, keberhasilan umat pada kedua Hijriyah dan ketiga Hijriyah dalam menancapkan pilar-pilar peradaban dan pemikiran mengantarkan umat Islam pada zaman keemasan. Di pihak lain, memberikan kemungkinan keretakan antarumat Islam sendiri meskipun ada keinginan untuk mendamaikan perkembangan yang tampak saling bertentangan. Kedua, Rabi'ah al'Adawiyah, Zunnun al-Mishri dan alGhazali dalam meletakkan dasar-dasar ajaran tasawuf tidak luput dari konteks tersebut. Rabi'ah dan Zunnun sama-sama hidup dalam situasi dimana umat sibuk mengurus hal-hal yang sifatnya eksoteris yang tidak menembus pada dimensi esoteris Islam. Keduanya telah menggeser dari paradigma ibadah yang dipegangi oleh umat Islam di zamannya, dari takut kepada Allah menjadi cinta kepada Allah. Sementara alGhazali hidup dalam keadaan pertentangan antar berbagai golongan Islam. Mahabbah dan ma'rifah yang diajarkan oleh ketiga sufi itu merupakan implementasi individuasi kesalehan dalam proses pencarian kebenaran yang dilingkupi pluralitas dan kosmopolitanisme sebuah fase peradaban.

36 Tamim Ansary, Dari Puncak Bagdad Sejarah Dunia Versi Islam, (terj.) Yuliani Liputo, (Jakarta: Zaman, 2015), hlm. 191. 
Ketiga, mahabbah dan ma'rifah adalah tujuan utama dalam ajaran tasawuf. Keduanya merupakan penghayatan atau pengalaman kejiwaan. Alat untuk menghayati Zat Allah bukan pikiran atau pancaindera, akan tetapi dengan hati atau qalb. Dalam tasawuf, hati atau qalb merupakan organ yang amat penting, karena dengan mata hati para sufi bisa menghayati segala rahasia yang ada dalam alam ghaib dan puncaknya adalah penghayatan ma'rifah pada Zat Allah. Mahabbah dan ma'rifah merupakan puncak ectasy atau "orgasme spiritual" yang didambakan oleh para sufi.

\section{DAFTAR PUSTAKA}

Abdullah, Taufik. Ensiklopedi Islam, Jakarta: PT. Ichtiar Baru Van Hoeve, 1993.

Al-Ghazali, Pembebas dari Kesesatan, (terj.) Abdullah Bin Noer, Jakarta: Tinta Mas, 1980. Cinta dan Bahagia, (terj.) Abd. Bin Nuh, Jakarta: Tinta Mas, 184. Mutiara Ihya' Ulumuddin, (terj.) Ru'san, Jakarta: Mulia, 1963.

Ansary, Tamim. Dari Puncak Bagdad Sejarah Dunia Versi Islam, (terj.) Yuliani Liputo, Jakarta: Zaman, 2015.

Arberry, A. J. Pasang Surut Aliran Tasawuf, (ter.) Bambang Hearawan), Bandung: Mizan, 1985.

Basil, Victor Said. Al-Ghazali Mencari Ma'rifah (terj.) Ahmadi Thaha, Jakarta: Pustaka Panjimas, 1990.

Danner, Victor. "Perkembangan Awal Tasawuf" dalam Seyyed Hossein Nasr (ed.), Esiklopedi Tematis Spiritualitas Islam: Fondasi, (ter. Rahmani Astuti), Bandung: Mizan, 2003.

Hamka, Tasawuf: Perkembangan dan Pemurniannya, Jakarta: Pustaka Panjimas, 1984.

Ibnu Khaldun, Muqaddimah, (ter.) Ahmadi, Jakarta: Pustaka Firdaus, 1986.

Madjid, Nurcholish. Islam Doktrin dan Peradaban, Jakarta: Paramadina, 1995. Kaki Langit Peradaban Islam, Jakarta: Paramadina, 1997.

Mulyati, Sri. dkk., Mengenal dan Memahami Tarekat-Tarekat Muktabarh di Indonesia, Jakarta: Kencana, 2006.

Nasr, Seyyed Hossein. Tasawuf Dulu dan Sekarang (terj.) Abdul Hadi WM, Jakarta: Pustaka Firdaus, 1985.

Nasution, Hanrun. "Tasawuf" dalam Budhy Munawar Rahman (Ed.), Kontekstualisasi Doktrin Islam dalam Sejarah, Jakarta: Paramadina: 1995.

Nicholson, Reynold A. The Mystics of Islam, London: Routledge and Kegan Paul, 1963.

Noer, Kautsar Azhari. Ibnu 'Arabi: Wahdat al-Wujud dalam Perdebatan, Jakarta: Paramadina, 1997.

Noer, Kautsar Azhari. Tasawuf Perennial, Jakarta: Serambi, 2006.

Nurbakhsh, Javad. Wanita-wanita Sufi, Bandung: Mizan, 1996.

Rahman, Fazlur. Islam: Sejarah Pemikiran dan Peradaban, (terj.) M. Irsyad Rafsadie, Bandung: Mizan, 2017.

Simuh, Tasawuf dan Perkembangannya dalam Islam, Jakarta: Rajawali Pers, 1996

Smith, Margareth. Reading from the Mystics of Islam, London: Moutan, 1950.

Syukur, Amin. Zuhud di Abad Modern, Yogyakarta: Pustaka Pelajar, 1987. 
Watt, Montgomery. Pemikiran dan Teologi dan Filsafat Islam (terj.) Umar Basalim, Jakarta: P3M, 1987.

Kejayaan Islam: Kajian Kritis dari Tokoh Orientalis (ter.) Hartono, Yogyakarta: Tiara Wacana, 1990. 